\title{
Detection of ostreid herpesvirus-1 (OsHV-1) by PCR using a rapid and simple method of DNA extraction from oyster larvae
}

\author{
Frederico M. Batista ${ }^{1,2}$, Nicolas Taris ${ }^{2}$, Pierre Boudry ${ }^{2}$, Tristan Renault ${ }^{2, *}$ \\ ${ }^{1}$ Instituto Nacional de Investigação Agrária e das Pescas (INIAP/IPIMAR), CRIPSul, Av. 5 de Outubro, 8700-305 Olhão, Portugal \\ ${ }^{2}$ Institut Français de Recherche pour l'Exploitation de la Mer (IFREMER), Laboratoire de Génétique et Pathologie (LGP), \\ 17390 La Tremblade, France
}

\begin{abstract}
A DNA extraction procedure was developed for the detection of ostreid herpesvirus-1 (OsHV-1) using the polymerase chain reaction (PCR) in oyster larvae. The DNA extraction procedure developed was tested on 8 larval samples. Abnormal nuclei with characteristic features associated with OsHV-1 infections were only observed in samples in which the viral DNA was detected by PCR. A previously described competitive PCR method was applied to detect inhibition during PCR reactions. The results show that the method can be used on small amounts of oyster larvae ( $3 \mathrm{mg})$ for the detection of OsHV-1 DNA by PCR.
\end{abstract}

KEY WORDS: Herpesvirus · OsHV-1 - Oyster $\cdot$ Larvae $\cdot$ Detection $\cdot$ DNA extraction - Resale or republication not permitted without written consent of the publisher

\section{INTRODUCTION}

Herpes-like virus infections of bivalve molluscs were first reported in Crassostrea virginica by Farley et al. (1972). Viruses presumed to belong to the Herpesviridae family have subsequently been associated with mortalities in larvae and juveniles of various bivalve species around the world (Hine et al. 1992, Nicolas et al. 1992, Renault et al. 1994, Renault \& Arzul 2001). The pathogenicity of the herpes-like virus infecting Crassostrea gigas larvae was demonstrated by experimental transmission of the disease to axenic healthy larvae (Le Deuff et al. 1994). The virus was isolated from moribund Crassostrea gigas larvae and its genome characterized (GenBank number AY509253), which allowed it to be included in the Herpesviridae family. The virus was named ostreid herpesvirus-1 (OsHV-1) (Minson et al. 2000, Arzul \& Renault 2002, Davison 2002). The characterization of the virus genome has facilitated the development of molecular tools including detection of viral DNA using the polymerase chain reaction (PCR) (Renault et al. 2000, Arzul et al. 2001, 2002, Lipart \& Renault 2002). PCR is a suit- able tool for the diagnosis of OsHV-1 infections due to specificity, high sensitivity, time and cost efficiency. The method used to prepare samples for DNA detection using the PCR is known to be critical for the success of the amplification reaction. The procedure currently used for preparing samples for OsHV-1 detection using the PCR (Renault et al. 2000) requires large amounts of larvae (50 $\mathrm{mg}$ ). The aim of the present study was to develop an alternative rapid and simple procedure of DNA extraction for small samples of oyster larvae $(3 \mathrm{mg}$ ) that allows the detection of OsHV-1 DNA using PCR.

\section{MATERIALS AND METHODS}

Oyster samples. Larvae from a hybridization study between Crassostrea angulata and C. gigas were reared in 4 independent $150 \mathrm{l}$ tanks. Larvae were collected in September 2003 after 10 and 15 d of development, and fresh-frozen at $-80^{\circ} \mathrm{C}$.

Sample preparation. Two procedures for total nucleic acid extraction were carried out: (1) a DNA 
sample preparation procedure previously described (Renault et al. 2000), (2) a variation of this procedure using a pre-treatment with Proteinase K/Tween-20. In the first extraction procedure (1), $50 \mathrm{mg}$ of frozen larvae were measured in $1.5 \mathrm{ml}$ microfuge tubes and ground in $50 \mu \mathrm{l}$ of distilled water. Samples were vortexed and boiled in a water bath for $10 \mathrm{~min}$, followed by quick chilling in ice (Renault et al. 2000). In the second extraction procedure (2), $3 \mathrm{mg}$ of fresh-frozen larvae were measured in $0.2 \mathrm{ml}$ microtube and washed in double distilled water to remove any traces of seawater. Larvae were then ground in $50 \mu \mathrm{l}$ of extraction buffer solution $(5 \mu$ of Goldstar Taq DNA Polymerase buffer, $45 \mu \mathrm{l}$ of double distilled water and $0.5 \%$ of Tween-20) using a single-use curved steel needle. Five microlitres of Proteinase $\mathrm{K}\left(10 \mathrm{mg} \mathrm{ml}^{-1}\right)$ were added to each tube. The samples were then incubated at $55^{\circ} \mathrm{C}$ for $60 \mathrm{~min}$ followed by a second incubation step at $100^{\circ} \mathrm{C}$ for $20 \mathrm{~min}$ in a thermal cycler (PTC-100 ${ }^{\mathrm{TM}}$, MJ Research). Samples were then mixed and centrifuged at $10000 \mathrm{rpm}(1200 \times g)$ for $5 \mathrm{~min}$ at $4^{\circ} \mathrm{C}$. Supernatants obtained by both procedures were recovered in $0.5 \mathrm{ml}$ microfuge tubes, diluted 10-fold in double distilled water and immediately frozen at $-20^{\circ} \mathrm{C}$.

Detection of OsHV-1 by nested PCR. Two primerpair combinations were used for the detection of OsHV-1 DNA, the external C5 (5' CCG TGA CTT CTA TGG GTA TGT CAG 3')/C13 (5' CCT CGA GGT AGC TTT TGT CAA G $3^{\prime}$ ) combination which generated a 765 bp product, followed by the internal C2 (5' CTC TTT ACC ATG AAG ATA CCC ACC 3')/C4 (5' GCA GTT GTG GTA TAC TCG AGA TTG $3^{\prime}$ ) pair which yielded a 352 bp product (Arzul et al. 2001). All PCR reactions were performed on a Crocodile III thermal cycler (Appligene Oncor). Fifty microlitre PCR reactions were prepared using 2.5 $\mathrm{U}$ of Goldstar Taq DNA Polymerase (Eurogentec), $0.05 \mathrm{mM}$ of each dNTP, $100 \mathrm{ng}$ of each primer, $2.5 \mathrm{mM} \mathrm{MgCl}{ }_{2}$ and $1 \mu \mathrm{l}$ of extracted DNA. After heating samples for $2 \mathrm{~min}$ at $94^{\circ} \mathrm{C}, 35$ cycles consisting of $94^{\circ} \mathrm{C}$ for $1 \mathrm{~min}, 50^{\circ} \mathrm{C}$ for $1 \mathrm{~min}$ and $72^{\circ} \mathrm{C}$ for $1 \mathrm{~min}$ were carried out, followed by a final elongation step of $5 \mathrm{~min}$ at $72^{\circ} \mathrm{C}$. Nested PCR was carried out using $0.5 \mu \mathrm{l}$ of the primary reaction as template following identical reaction conditions. Negative controls were incorporated in all PCR runs containing all the PCR reagents and double distilled water instead of template DNA. Genomic OsHV-1 DNA extracted from purified virions infecting Crassostrea gigas larvae (Le Deuff \& Renault 1999) were used as positive control.

PCR inhibition controls. A competitive PCR method previously developed (Arzul et al. 2002, Renault et al. 2004) was used to detect inhibition during PCR reactions using the primer pair C2 (5'-CTC TTT ACC ATG AAG ATA CCC ACC-3')/C6 (5'-GTG CAC GGC TTA
CCA TTT TT-3'). These primers amplify an OsHV-1 DNA fragment of $710 \mathrm{bp}$ as well as an internal standard competitor that differs from the target viral DNA by a 76 base pair deletion. One microliter of both extracted and competitor DNA was added to the reaction mixture, while the conditions for the PCR reaction were the same as described in the previous paragraph. For the internal standard control, $1 \mu \mathrm{l}$ of double distilled water was added instead of extracted DNA.

Detection of oyster DNA. A $16 \mathrm{~S}$ mitochondrial fragment (16SrDNA: the large subunit rRNA-coding gene) was amplified from the oyster larvae following the protocol of Boudry et al. (1998) using the primers described by Banks et al. (1993).

Electrophoresis of PCR products. All PCR products were visualized by electrophoresis in $1.5 \%$ agarose gels containing ethidium bromide $\left(0.5 \mathrm{mg} \mathrm{l}^{-1}\right)$ in $1 \mathrm{X}$ Tris-acetate-EDTA (TAE) buffer $(40 \mathrm{mM}$ Tris-acetate, 1 mM EDTA, pH 8.0). Molecular mass markers (100 bp DNA ladder, Promega) were included in each gel to determine the approximate size of the PCR products, and DNA bands were photographed under UV transillumination.

Microscopical examination. Larvae were fixed in $2.5 \%$ glutaraldehyde in $0.2 \mathrm{M}$ cacodylate buffer at $\mathrm{pH} 7.2$ at $4^{\circ} \mathrm{C}$. After 2 washes in $0.2 \mathrm{M}$ cacodylate buffer, samples were then post-fixed in $1 \%$ osmium tetroxide in the same buffer at $4^{\circ} \mathrm{C}$. Larval samples were dehydrated by serial ethanol baths ( 70 to $100 \%$ ), cleared twice for $15 \mathrm{~min}$ in propylene oxide and infiltrated for $1 \mathrm{~h}$ in 50:50 propylene oxide:Epon resin. After $1 \mathrm{~h}$ infiltration in pure Epon resin, they were embedded in resin and cured for $48 \mathrm{~h}$ at $60^{\circ} \mathrm{C}$. One micrometer sections were stained with $0.5 \%$ toluidine blue in $1 \%$ sodium borate solution for light microscopic examination.

\section{RESULTS AND DISCUSSION}

PCR products with the expected size were observed after the first $(\mathrm{C} 5 / \mathrm{C} 13)$ and second $(\mathrm{C} 2 / \mathrm{C} 4)$ reactions in one (15 d old Crassostrea gigas larvae) of the 8 analysed samples using both DNA extraction methods. Cells with enlarged nuclei of abnormal shape and chromatin pattern characteristic of herpes-like viral infections in mollusc bivalves (Hine et al. 1992, Renault et al. 1994) were observed in semi-thin sections in the $15 \mathrm{~d}$ old larvae in which the virus was detected by PCR. No nuclear abnormalities were observed in the 7 samples that did not yield PCR products. These results suggest that: (1) only 1 of the larval batches was infected with OsHV-1 and (2) that the DNA extraction method used was sensitive enough to allow the detection of OsHV-1 DNA from a small amount of larvae. This conclusion is further supported by the mortality 
rate of $100 \%$ ( $3 \mathrm{~d}$ after the detection of OsHV-1 using PCR) in the infected larval batch, while no subsequent abnormal mortality was observed (data not shown) in any other batch in which the virus was not detected by PCR. The absence of OsHV-1 detection in other batches does not necessarily demonstrate the complete absence of the virus, as low levels of viral DNA in larval tissues may be below the threshold of our methods.

Factors that inhibit the PCR reaction can interfere by nucleic acid degradation or capture and may inhibit polymerase activity for amplification of the target DNA (Wilson 1997). No inhibitory effect was detected in the samples obtained by both DNA extraction methods (Fig. 1). Amplification of the internal standard (634 bp) was observed in all samples in which the nested PCR did not detect the viral DNA. In the positive sample a band of expected size (710 bp) corresponding to viral DNA was observed, as well as a lighter band corresponding to the internal standard (634 bp) (Fig. 1, Lane 7).

False-negative results can also result from inadequate cell lysis and subsequently low levels of DNA for amplification (Wilson 1997). Extraction by boiling alone has been noted to reduce PCR sensitivity due to poor lysis efficiency and insufficient separation of DNA from structural proteins (Todd et al. 1992). Moreover, the high concentration of salt in fresh frozen larvae can inhibit cell lysis and negatively affect PCR. The combined use of Proteinase K/Tween-20 and larval wash with distilled water may thus improve cell lysis and hence increase the efficiency of PCR (Estoup et al.

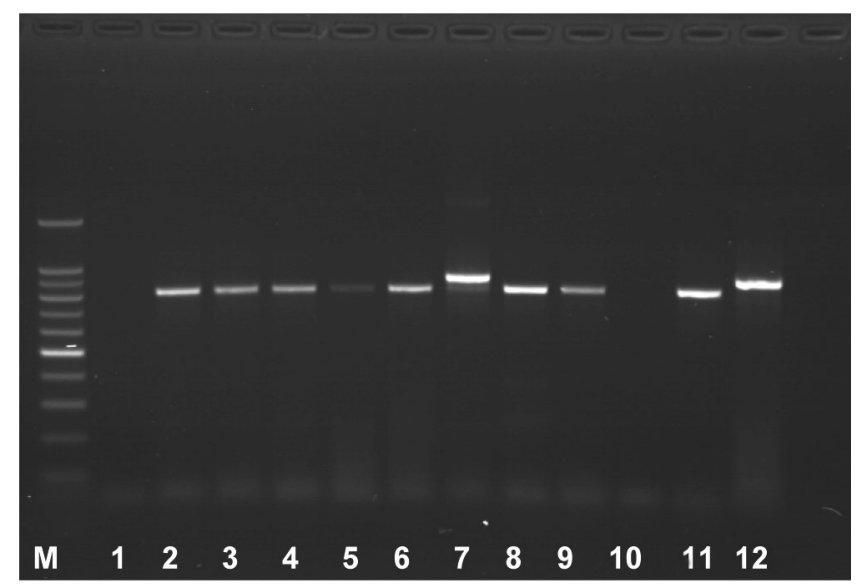

Fig. 1. Ostreid herpesvirus-1. Inhibition controls using a competitive PCR method. Lanes 1 and 10: negative controls; Lanes 2 and 6: 10 and 15 d old larvae (dol) from Tank 1, respectively; Lanes 3 and 7: 10 and 15 dol from Tank 2, respectively; Lanes 4 and 8: 10 and 15 dol from Tank 3, respectively; Lanes 4 and 8: 10 and 15 dol from Tank 4, respectively; Lane 11: internal standard; Lane 12: genomic viral DNA; Lane M: size markers (100 bp DNA ladder, Promega)
1996). On the other hand, alternative methods of DNA extraction from Crassostrea gigas larvae including Chelex-100 and phenol/chloroform extractions occasionally yield false-negative results (Renault et al. 2000). We successfully amplified the oyster 16S fragments in all our samples (data not shown), hence supporting our extraction methods for good quality DNA.

The DNA extraction procedure described is simple and rapid, and allows the detection of OsHV-1 DNA from small amounts of oyster larvae $(3 \mathrm{mg})$. Moreover, the number of required steps is low when compared to other extraction protocols, hence reducing the risk of sample contamination. This method can be useful for disease diagnosis and studies concerning the mechanisms involved in infections by OsHV-1 when only small quantities of larvae are available. Furthermore, this method may also be used for detection of the virus by PCR in individual larva since it was successfully used in extracting DNA from single Crassostrea gigas larva for microsatellite multiplexing (Taris unpubl. data). Therefore, this method can open new perspectives in studies concerning OsHV-1 transmission and putative resistance in early life stages.

Acknowledgements. We are grateful to Dr. P. Goulletquer for facilitating this work at the IFREMER station in La Tremblade (Charente Maritime, France). We also thank Dr. T. Sharbel for critical comments on the manuscript. This work was made possible by a FCT grant (SFRH/BD/8972/2002) and a Marie Curie Training fellowship (PLUDAMOR, QLK5-CT-200060036) to F.M.B.

\section{LITERATURE CITED}

Arzul I, Renault T (2002) Herpèsvirus et bivalves marins. Virologie 6:169-174

Arzul I, Renault T, Lipart C, Davison AJ (2001) Evidence for interspecies transmission of oyster herpesvirus in marine bivalves. J Gen Virol 82:865-870

Arzul I, Renault T, Thebault A, Gérard A (2002) Detection of oyster herpesvirus DNA and proteins in asymptomatic Crassostrea gigas adults. Virus Res 84:151-160

Banks MA, Hedgecock D, Waters C (1993) Discrimination between closely related Pacific oyster species (Crassostrea) via mitochondrial DNA sequences coding for large subunit rRNA. Mol Mar Biol Biotechnol 2(3):129-136

Boudry P, Heurtebise S, Collet B, Cornette F, Gérard A (1998) Differentiation between populations of the Portuguese oyster, Crassostrea angulata (Lamark) and the Pacific oyster, Crassostrea gigas (Thunberg), revealed by mtDNA RFLP analysis. J Exp Mar Biol Ecol 226:279-291

Davison AJ (2002) Evolution of the herpesviruses.Vet Microbiol 86(1-2):69-88

Estoup A, Largiadèr CR, Perrot E, Chourrout D (1996) Rapid one-tube DNA extraction for reliable PCR detection of fish polymorphic markers and transgenes. Mol Mar Biol Biotechnol 5(4):295-298

Farley CA, Banfield WG, Kasnic JRG, Foster WS (1972) Oyster herpes-type virus. Science 178:759-760 
Hine PM, Wesney B, Hay BE (1992) Herpesviruses associated with mortalities among hatchery-reared Pacific oysters, Crassostrea gigas. Dis Aquat Org 12:135-142

Le Deuff RM, Renault T (1999) Purification and partial genome characterization of a herpes-like virus infecting the Japanese oyster, Crassostrea gigas. J Gen Virol 80: $1317-1322$

Le Deuff RM, Nicolas JL, Renault T, Cochennec N (1994) Experimental transmission of herpes-like virus to axenic larvae of the Pacific oyster, Crassostrea gigas. Bull Eur Assoc Fish Pathol 14(2):69-72

Lipart C, Renault T (2002) Herpes-like virus detection in infected Crassostrea gigas spat using DIG-labelled probes. J Virol Methods 101:1-10

Minson AC, Davison A, Eberle R, Desrosiers RC and 5 others (2000) Family Herpesviridae. In: von Regenmortel MHV, Fauquet CM, Bishop DHL, Carsten EB and 7 others (eds) Virus taxonomy. Seventh Report of the International Committee on Taxonomy of Viruses. Academic Press, New York, p 203-225

Nicolas JL, Comps M, Cochennec N (1992) Herpes-like virus

Editorial responsibility: Albert Sparks,

Seattle, Washington, USA infecting Pacific oyster larvae, Crassostrea gigas. Bull Eur Assoc Fish Pathol 12(1):11-13

Renault T, Arzul I (2001) Herpes-like virus infections in hatchery-reared bivalve larvae in Europe: specific viral DNA detection by PCR. J Fish Dis 24:161-167

Renault T, Le Deuff RM, Cochennec N, Maffart P (1994) Herpesviruses associated with mortalities among Pacific oyster, Crassostrea gigas, in France-comparative study. Revue Méd Vét 134(10):735-742

Renault T, Le Deuff RM, Lipart C, Delsert C (2000) Development of a PCR procedure for the detection of a herpes-like virus infecting oysters in France. J Virol Methods 88:41-50

Renault T, Arzul I, Lipart C (2004) Developement and use of an internal standard for oyster herpesvirus detection by PCR. J Virol Methods 121:17-23

Todd D, Mawhinney KA, McNulty MS (1992) Detection and differentiation of chicken virus isolates by using the polymerase chain reaction. J Clin Microbiol 30(7): 1661-1666

Wilson IG (1997) Inhibition and facilitation of nucleic acid amplification. Appl Environ Microbiol 63(10):3741-3751

Submitted: June 12, 2004; Accepted: September 22, 2004 Proofs received from author(s): February 25, 2005 